\title{
Biglycan as a potential diagnostic and prognostic biomarker in multiple human cancers
}

\author{
SHOU-FENG ZHAO ${ }^{1}$, XUE-JING YIN ${ }^{2}$, WEN-JU ZHAO ${ }^{3}$, LE-CUI LIU ${ }^{4}$ and ZHI-PENG WANG ${ }^{5}$ \\ ${ }^{1}$ Central Laboratories, Qingdao Municipal Hospital, Qingdao, Shandong 266000; ${ }^{2}$ Department of Pharmacy, \\ Qingdao Mental Health Centre; ${ }^{3}$ Operating Room, Qingdao Jinhua Gynecology Hospital, Qingdao, Shandong 266235; \\ ${ }^{4}$ Neonatal Department, Wulian County People's Hospital, Wulian, Shandong 262300; ${ }^{5}$ Marine Science and \\ Engineering College, Qingdao Agricultural University, Qingdao, Shandong 266109, P.R. China
}

Received February 16, 2019; Accepted August 16, 2019

DOI: $10.3892 / \mathrm{ol} .2020 .11266$

\begin{abstract}
Biglycan (BGN), a key member of the small leucine-rich proteoglycan family, is an important component of the extracellular matrix. Clinical studies have demonstrated that upregulation of BGN is associated with poor prognosis in patients with various types of solid cancer. The present study analyzed the mRNA expression levels of BGN in various types of solid cancer when compared with that in normal tissues via the Oncomine database. The UALCAN, OncoLnc and Kaplan-Meier Plotter databases were additionally used to evaluate the prognostic values of BGN in patients with solid cancer and co-expression gene analysis was conducted using the protein-protein interaction networks of BGN. The present study observed that the mRNA expression levels of BGN were increased in bladder, brain and central nervous system, breast, colorectal, esophageal, gastric, head and neck, lung, ovarian and 28 subtypes of cancer compared with normal tissues. The increased expression of BGN was identified to be associated with a poor outcome in ovarian and gastric cancer. Based on the co-expression network, BGN was identified as the key gene in a 43-gene network. The present findings of increased expression of BGN in solid tumors and its positive association with poor outcome on patient survival indicate that BGN may serve as a prognostic marker and as a target for novel therapeutics for multiple types of cancer.
\end{abstract}

\section{Introduction}

Cancer is considered as one of the four major non-communicable diseases (1). Due to a delay in diagnosis, its poor prognosis and high recurrence rate, cancer is becoming one of the leading causes of mortality worldwide $(2,3)$. Cancer incidence

Correspondence to: Dr Zhi-Peng Wang, Marine Science and Engineering College, Qingdao Agricultural University, 17 Wenhai Road, Jimo, Qingdao, Shandong 266109, P.R. China

E-mail: wangzp@ysfri.ac.cn

Key words: biglycan, biomarker, cancer and mortality rates have increased over the last decade. The global cancer burden is estimated to have risen to 18.1 million new cancer cases, and 9.6 million cancer-associated mortalities were reported in 2018 (4), compared with 12.7 million and 7.6 million, respectively, in 2008 (5). Therefore, there is an urgent need to explore novel potential cancer biomarkers that will have beneficial prognostic and therapeutic implications.

Biglycan (BGN; also known as proteoglycan-1 and dermatan sulfate PG-1) is a single-copy gene localized on the long arm of human $\mathrm{X}$ chromosome Xq13-qter (6). This gene contains at least two introns and it spans $\sim 6 \mathrm{~kb}$ in length (7). $\mathrm{BGN}$ is a key member of the small leucine-rich proteoglycan family that resides at the cell surface or in the pericellular space of tissues (8). BGN is typically expressed in the nerve, bone, cartilage, skin and muscles, modulating the morphology, growth, adhesion, bone mineralization, inflammation, migration and differentiation of epithelial cells (9). The upregulation of BGN has been reported in multiple types of solid cancer, including ovarian carcinoma (10), prostate cancer (11), pancreatic cancer (12), gastric cancer (13) and colon cancer (14). Overexpressed BGN has been reported to be associated with the aggressive growth and metastasis of tumors $(13,14)$, and with a worse prognosis for patients with gastric cancer (15) and pancreatic adenocarcinoma (16). These findings suggest that the $B G N$ gene may act as either a potential therapeutic target or prognostic biomarker in multiple types of cancer. However, the transcriptional expression and prognostic value of the $B G N$ gene in human cancers requires further investigation.

The present study investigated the mRNA expression levels of BGN in human normal and cancer tissues, using the Oncomine database. In addition, the prognostic value of BGN mRNA expression in patients with cancer was also assessed using the UALCAN, OncoLnc and the Kaplan-Meier Plotter databases. Finally, co-expression gene analysis was conducted using the protein-protein interaction (PPI) networks of BGN.

\section{Materials and methods}

Analysis of BGN expression in multiple cancers using Oncomine. Oncomine is a cancer microarray database and web-based data-mining platform aimed at facilitating discovery from genome-wide expression analyses, as well as 
comparing the transcriptome data in multiple types of cancer, respective to normal tissues (17). To date, the Oncomine database contains 19 cancer types, 715 datasets and 86,733 samples, corresponding to $\sim 48$ million gene expression measurements. Differential mRNA level analyses of BGN were compared between normal tissues and malignant human tissues in different types of cancer, using the Oncomine database. In the present study, the thresholds were set at 2-fold change, $\mathrm{P}<1 \times 10^{-4}$ and the top $10 \%$ gene rank.

Analysis using the Kaplan-Meier (KM) plotter, UALCAN and OncoLnc databases. The prognostic significance of the mRNA expression levels of BGN in various types of cancer was evaluated using KM plotter (http://www.kmplot.com), UALCAN (http://ualcan.path.uab.edu) and OncoLnc (http://oncolnc.org). These online databases can be used to assess the effect of gene expression on cancer prognosis. The three databases of KM plotter, OncoLnc and UALCAN contain the same RNA-seq data (from TCGA) for 20 http://www.kmplot.com/analysis/ index.php?p=service \&cancer=pancancer_rnaseq, 21 (18) and 35 (19) types and subtypes of cancer, respectively. KM plotter also contain the gene chip data [from GEO (breast cancer: GSE12276, GSE16391, GSE12093, GSE11121, GSE9195, GSE7390, GSE6532, GSE5327, GSE4922, GSE3494, GSE2990, GSE2034, GSE1456; ovarian cancer: GSE14764, GSE15622, GSE19829, GSE3149, GSE9891, GSE18520, GSE26712; lung cancer: GSE4573, GSE14814, GSE8894, GSE19188, GSE3141, GSE31210, GSE29013, GSE37745; gastric cancer: GSE44740, GSE51725, GSE13911, GSE43346, and GSE3526)] (20-23) for breast cancer (BC), lung cancer (LC), gastric cancer (GC) and ovarian cancer (OC). Therefore, the prognostic significance of the mRNA expression levels of BGN in various types of carcinomas, including BC, LC, GC and OC was evaluated using RNA-seq data and confirmed by gene chip data. The overall survival rate (OS) in patients with other types and subtypes of carcinomas was estimated using RNA-seq by KM plotter, OncoLnc or UALCAN databases.

The KM plotter is able to assess the effect of 54,675 genes on survival using 10,461 cancer samples. In this database, the types and subtypes of cancer samples were observed from RNA-sequencing (RNA-seq) data while the lung (22), ovarian (21), gastric (23), and breast (20) cancer samples were also analyzed from gene chip microarrays.

Patient samples were divided into two cohorts according to the median expression of the $B G N$ gene (high vs. low expression). The present study analyzed the overall survival (OS) in patients using a Kaplan-Meier survival plot. Briefly, the $B G N$ gene was uploaded into the respective databases to obtain the Kaplan-Meier survival plots, in which the number-at-risk was presented below the main plot. Affymetrix ID (or RNA-seq ID), log rank P-value and hazard ratio (HR) with $95 \%$ confidence intervals were calculated and displayed on the webpage. $\mathrm{P}<0.05$ was considered to indicate a statistically significant difference.

UALCAN, is an interactive web resource for analyzing cancer transcriptome data, built on PERL-common gateway interface with high quality graphics using JavaScript and Cascading Style Sheets. UALCAN was used to construct an algorithm based on The Cancer Genome Atlas (TCGA) level 3 RNA-seq database (https://portal.gdc.cancer.gov/). UALCAN can provide publication quality graphs and plots depicting gene expressions and patient survival information based on gene expression (19). $\mathrm{P}<0.05$ was considered to indicate a statistically significant difference.

OncoLnc is a tool for interactively exploring survival correlations. OncoLnc contains survival data for 8,647 patients from 21 cancer studies performed by TCGA, along with RNA-seq expression for mRNAs and microRNAs from TCGA and long non-coding RNA expressions from MiTranscriptome ( $\beta$ release) (http://www.mitranscriptome.com/). OncoLnc stores precomputed survival analyses, allowing users to quickly explore survival correlations for up to 21 types of cancer in a single click (18). The $B G N$ gene was uploaded into the database to obtain the patient survival information. $\mathrm{P}<0.05$ was considered to indicate a statistically significant difference.

Co-expression and PPI network construction. The present study extracted the top 50 co-expressed genes that have similar expression pattern with $B G N$ gene, based on Pearson correlation score across all tumor samples from the GEPIA database (http:/gepia.cancerpku.cn/index.html). Then, the 11.0 Search Tool for the Retrieval of Interacting Genes/Proteins database (http://string-db.org/), was used to construct a PPI network with these co-expressed genes (24). The PPI pairs were extracted with a combined score of 0.4. Subsequently, the PPI network was visualized using the Cytoscape 3.7.0 software (http://www.cytoscape.org/).

\section{Results}

Increased expression of BGN in multiple types of solid cancer. As illustrated in Fig. 1, Oncomine contained a total of 421 research studies for the $B G N$ gene. In 78 analyses, $B G N$ exhibited statistically significant differences, 5 of which revealed lower mRNA expression levels in solid tumors compared with normal tissues, while 73 analyses indicated the opposite result (Fig. 1). $B G N$ gene expression was the most upregulated in bladder, brain and central nervous system (CNS), breast, colorectal, gastric, head and neck, pancreatic cancer and other cancer, followed by esophageal, kidney, liver, ovarian cancer, and lung cancer (Fig. 1). Results in the investigation of $B G N$ gene expression have been inconsistent in a number of studies (25-33), including kidney, liver, pancreatic, and prostate cancer. The expression levels of BGN in cervical cancer and melanoma were not significantly changed (Fig. 1). The $B G N$ gene expression status in lymphoma, leukemia, sarcoma and myeloma was not analyzed in this study as they are not classified as solid cancers (34).

Solid cancers, in which BGN was reported to be upregulated consistently in different studies, were examined further in the various cancer subtypes using the Oncomine datasets. The data summarized in Table I revealed that there was a significant increase in expression of BGN in BLC, including subtype of IBLCA) $(n=53)$, when compared with that in normal tissues $(n=3)$ in the study by Blaveri et al (35). The BGN mRNA expression was significantly elevated in brain and CNS cancer, including subtype of GBM $(n=130)$ when compared with normal tissues $(n=30)$ in the study conducted by Bredel et al (36). The mRNA expression of BGN was significantly elevated in BC, including subtypes BRCA, DBC, 


\begin{tabular}{|c|c|}
\hline Analysis Type by Cancer & $\begin{array}{c}\text { Cancers } \\
\text { vs. } \\
\text { Nomal }\end{array}$ \\
\hline Bladder Cancer & 1 \\
\hline Brain and CNS Cancer & 3 \\
\hline Breast Cancer & 17 \\
\hline Cervical Cancer & \\
\hline Colorectal cancer & 13 \\
\hline Esophageal Cancer & 3 \\
\hline Gastric Cancer & 10 \\
\hline Head and Neck Cancer & 1 \\
\hline Kidney Cancer & 1 \\
\hline Leukemia & 1 \\
\hline Liver Cancer & 2 \\
\hline Lung Cancer & 1 \\
\hline Lymphoma & 7 \\
\hline Melanoma & \\
\hline Myeloma & \\
\hline Other Cancer & 3 \\
\hline Ovarian Cancer & 3 \\
\hline Pancreatic Cancer & 1 \\
\hline Prostate Cancer & 1 \\
\hline Sarcoma & 4 \\
\hline Significant Unique analyses & 73 \\
\hline Total Unique analyses & 421 \\
\hline
\end{tabular}

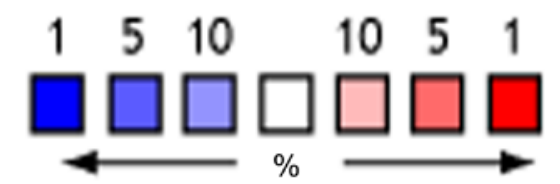

Figure 1. mRNA expression levels of BGN in different types of cancer from the Oncomine database. The schematic reveals the numbers of datasets with statistically significant mRNA overexpression (red) or underexpression (blue) of the target gene. Darker red indicates higher $B G N$ expression, Darker blue indicates lower $B G N$ expression. The color is determined by the best gene rank percentile for the analyses within the cell. The number in each cell represents the number of analyses that met the thresholds of: Gene, BGN; analysis type, cancer vs. normal; and data type, mRNA. The thresholds were set at 2 -fold change, $\mathrm{P}<1 \times 10^{-4}$ and the top $10 \%$ gene rank. For cervical cancer, melanoma, myeloma and prostate cancer, there was no analysis (white cell) that met the aforementioned thresholds. The gene rank was analyzed using the percentile of target gene in the top of all genes measured in each analysis. BGN, biglycan; CNS, central nervous system.

DCIS, IDBC, IDBCs, IDC, IDC-L, ILBC, ILC, LBC, MBC and TBC $(n=2,540)$ compared with that in normal tissues $(n=240)$, which was performed by Ma et al (37), Curtis et al (38), Karnoub et al (39), Perou et al (40), Zhao et al (41) and TCGA studies $(42,43)$ The mRNA expression of BGN was also significantly upregulated in $\mathrm{CC}$, including subtypes COAD, CMA, RSA, CeAC and READ ( $n=463$ ), when compared with that in normal tissues $(\mathrm{n}=150)$, which was reported in the studies conducted by Kaiser et al (44), Skrzypczak et al (45), Graudens et al (46), TCGA (47), Gaedcke et al (48), and Hong et al (49). BGN mRNA expression was also significantly upregulated in EC, including subtype ESCC $(n=84)$, when compared with that in normal tissues $(n=80)$, which was reported in the studies of Su et al (50), Hu et al (51) and Hao et al (52). BGN mRNA expression was also significantly higher in GC, including subtypes ITGA, DGAC and GMA $(\mathrm{n}=265)$, when compared with that in normal tissues $(\mathrm{n}=171)$, as reported by Chen et al (53), Cho et al (54), Wang et al (55), D'Errico et al (56) and Cui et al (57). The mRNA expression of BGN was also significantly increased in $\mathrm{HNC}$, including subtype SGACC $(\mathrm{n}=16)$ compared with that in normal tissues $(\mathrm{n}=6)$ in the study by Frierson et al (58). The mRNA expression of BGN was significantly higher in LC, including subtype SCC $(n=34)$ compared with that in normal tissues $(n=28)$ in the study by Talbot et al (59). The mRNA expression of BGN was increased significantly in OC, including subtypes SSPC and OSC $(\mathrm{n}=799)$ compared with that in normal tissues $(\mathrm{n}=22)$, as reported by Welsh et al (60), and Bonome et al (61), and studies listed in TCGA (62). The mRNA expression of BGN was increased significantly in other types of cancer, including subtype SBCC $(\mathrm{n}=15)$ compared with that in normal tissues $(\mathrm{n}=4)$, as reported by Riker et al (63). Therefore, the expression of BGN was significantly increased in human solid cancers, including 10 types and 28 subtypes of carcinoma. These results indicate that the mRNA expression of BGN is elevated in a wide range of tumors, when compared with that in normal tissues.

High BGN expression and survival outcome in multiple types of solid cancer. The expression of BGN was significantly increased in certain types of human solid cancers, including bladder, brain and CNS, breast, colorectal, gastric, head and neck, esophageal, ovarian, lung and other cancers, however there was no data on the downregulation of the BGN from the database (Table I). The present study used the Kaplan-Meier Plotter, OncoLnc and UALCAN databases to identify the association between survival time and the mRNA levels of BGN in patients with different types and subtypes of solid cancer.

As shown in Table II, $B G N$ gene with a significant association with patient survival can be identified in GC and OC $(\mathrm{P}<0.05)$. There is no significant association of $\mathrm{BGN}$ upregulation with patient survival in $\mathrm{BC}, \mathrm{EC}(\mathrm{P}>0.05)$, IBC, READ, COAD, and ESCC $(P>0.05)$. The survival rate of patients with LC with $\mathrm{P}>0.05$ in RNA-seq and $\mathrm{P}<0.05$ in microarray analysis requires further investigation. Therefore, high BGN mRNA expression may potentially be associated with the prognosis in patients with BLC, LSCC, and OSC, as the present analyses provided RNA-seq analysis results $(\mathrm{P}<0.05)$ without microarray analysis confirmation (Table II). The association between BGN mRNA expression and prognosis in patients with other types of cancer and subtypes of cancer requires further investigation as there is no prognostic data in the KM plotter, OncoLnc and UALCAN database (Table III).

As presented in Fig. 2, high expression of BGN was significantly associated with shorter OS time in patients with $\mathrm{GC}\left[\mathrm{HR}=1.9(1.56-2.32), \mathrm{P}=1.3 \times 10^{-10}\right.$ in microarry analysis; $\mathrm{HR}=1.59(1.13-2.24), \mathrm{P}=6.8 \times 10^{-3}$ in RNA-seq analysis] and 







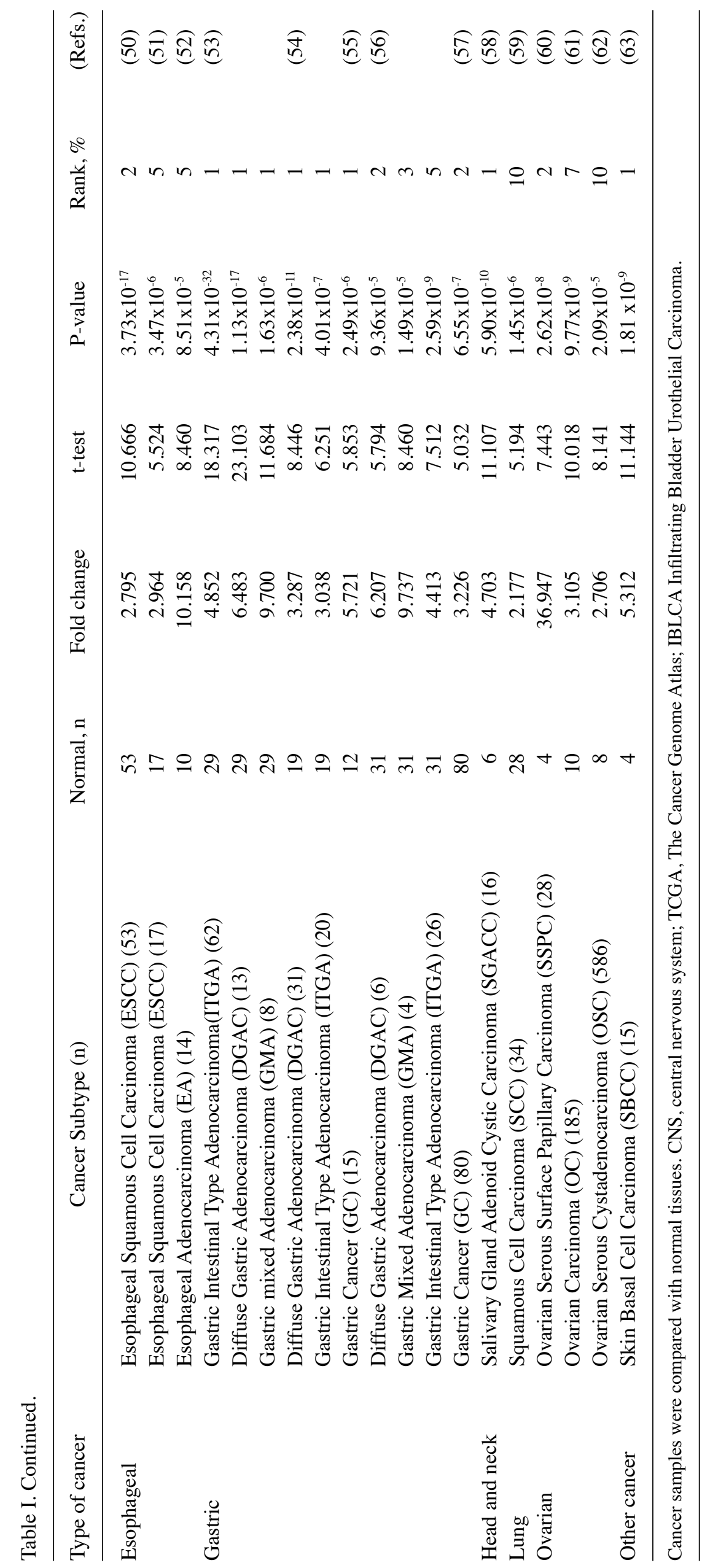


Table II. Overall survival of patients with different types of cancer with overexpressed $B G N$ gene.

\begin{tabular}{lcc}
\hline Cancer types & $\begin{array}{c}\text { RNA-seq } \\
\text { P-value (database) }\end{array}$ & $\begin{array}{c}\text { gene chip } \\
\text { P-value (database) }\end{array}$ \\
\hline Breast cancer & $0.2556^{\mathrm{a}}$ & $0.7210^{\mathrm{a}}$ \\
Esophageal & $0.0965^{\mathrm{a}}$ & $\mathrm{N} / \mathrm{A}$ \\
adenocarcinoma & & \\
Lung cancer & $0.3010^{\mathrm{a}}$ & $0.0002^{\mathrm{a}}$ \\
Gastric cancer & $0.0068^{\mathrm{a}}$ & $1.3 \times 10^{-10 \mathrm{a}}$ \\
Ovarian cancer & $0.0093^{\mathrm{a}}$ & $0.0004^{\mathrm{a}}$ \\
Bladder cancer & $0.0025^{\mathrm{a}}$ & $\mathrm{N} / \mathrm{A}$ \\
\hline
\end{tabular}

Calculated using a Kaplan-Meier Plotter databases with RNA-seq data and gene chip data. BGN, biglycan; N/A, not applicable.

Table III. Overall survival of patients with different subtypes of cancer with overexpressed $B G N$ gene.

\begin{tabular}{|c|c|c|}
\hline $\begin{array}{l}\text { Cancer } \\
\text { subtype }\end{array}$ & $\begin{array}{l}\text { RNA-seq } \\
\text { P-value } \\
\text { (database) }\end{array}$ & $\begin{array}{l}\text { gene chip } \\
\text { P-value } \\
\text { (database) }\end{array}$ \\
\hline Lung squamous cell carcinoma & $0.0111^{\mathrm{a}}$ & N/A \\
\hline $\begin{array}{l}\text { Ovarian serous } \\
\text { cystadenocarcinoma }\end{array}$ & $0.0290^{\mathrm{c}}$ & N/A \\
\hline Breast invasive carcinoma & $0.9400^{\mathrm{c}}$ & N/A \\
\hline Colon adenocarcinoma & $0.0963^{\mathrm{b}}$ & N/A \\
\hline Rectum adenocarcinoma & $0.1776^{\mathrm{a}}$ & N/A \\
\hline $\begin{array}{l}\text { Esophageal Squamous } \\
\text { Cell Carcinoma }\end{array}$ & $0.2707^{\mathrm{a}}$ & N/A \\
\hline
\end{tabular}

Calculated using ${ }^{\mathrm{a}}$ Kaplan-Meier Plotter databases, ${ }^{\mathrm{b}}$ OncoLnc and 'UALCAN with RNA-seq data. BGN, biglycan; N/A, not applicable.

OC [HR=1.28 (1.11-1.47), $\mathrm{P}=4.4 \times 10^{-4}$ in microarry analysis; $\mathrm{HR}=1.45$ (1.09-1.93), $\mathrm{P}=9.3 \times 10^{-3}$ in RNA-seq analysis].

In summary, high BGN mRNA expression in gastric cancer and ovarian cancer was significantly associated with poor overall survival. High BGN mRNA expression was indicated to be associated with poor clinical outcome in the prognosis of patients with bladder cancer, lung squamous cell carcinoma, and ovarian serous cystadenocarcinoma. However, the association between BGN mRNA upregulation and prognosis in patients with other types and subtypes of cancer requires further examination.

PPI network construction. The GEPIA database was used to download the top 50 co-expressed genes, then the PPI was generated (Fig. 3). In the network, BGN directly interacted with 42 neighboring genes, including ANTXR1, AEBP1, CDH11, CTHRC1, EFEMP2, FAP, LEPRE1, LRRC15, LUM, MMP14, MRC2, MXRA5, OLFML2B, PCOLCE, PDGFRB, PXDN, SERPINH1, SFRP2, SPARC, SULF1, TGF $33, T H B S 2$, $T H Y 1$, genes of the disintegrin and metalloproteinase gene


Figure 2. OS curves of patients with different types of cancer divided by BGN expression. High expression levels of the $B G N$ gene exhibited a significant association with lower OS time in patients with (A) gastric cancer (gene chip data), (B) gastric cancer (RNA-seq data), (C) ovarian cancer (gene chip data), (D) ovarian cancer (RNA-seq data). The plots were generated using the KM plotter database. The red lines indicate patients with $B G N$ gene expression above the median value, and the black lines indicate patients with $B G N$ gene expression below the median value. OS, overall survival; $B G N$, biglycan; HR, hazard ratio.

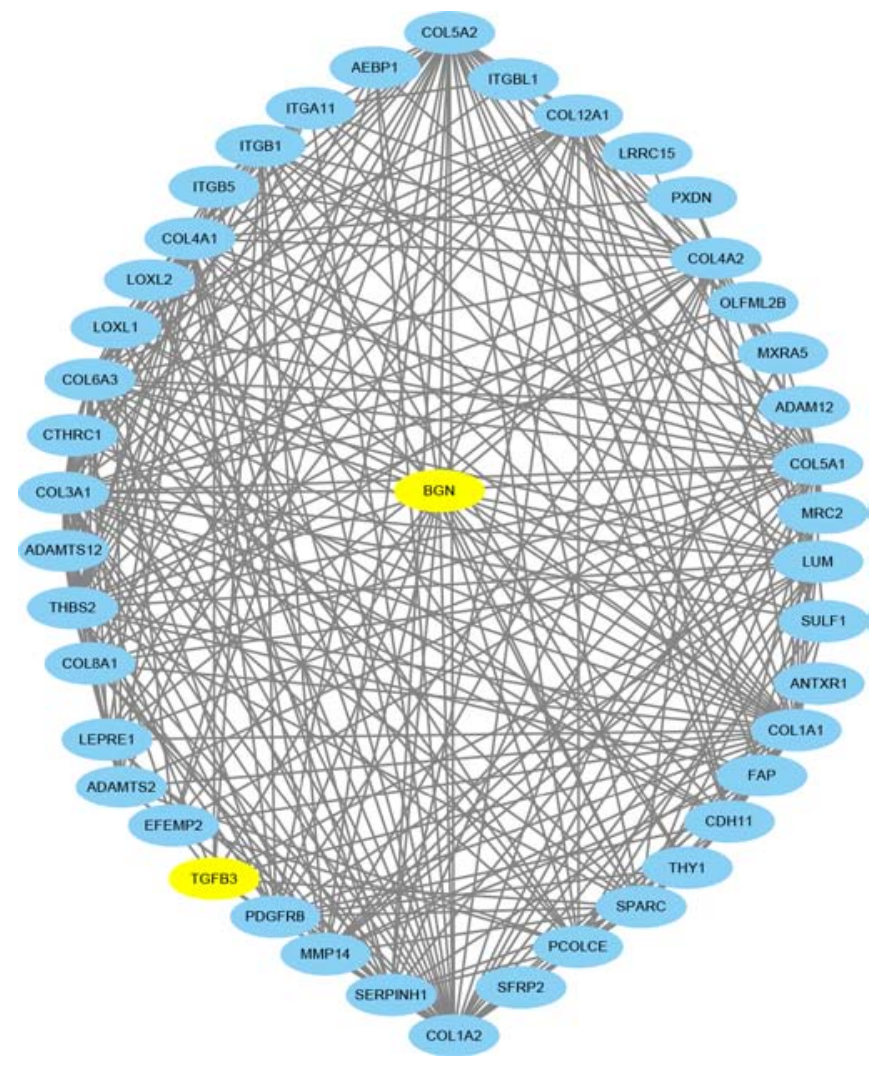

Figure 3. PPI network for BGN and its potential interacting proteins. Genes that were co-expressed in cancer together with BGN were extracted from the GEPIA database, and then a PPI network was established using the STRING database and visualized using the Cytoscape software. TGF 33 was highlighted in yellow because it may play an important role to regulate the expression of BGN. PPI, protein-protein interactions; BGN, biglycan; TGF $\beta 3$, transforming growth factor $\beta 3$. 
family, collagen family genes, the integrin subunit gene family and lastly the lysyl oxidase-like gene family, which jointly regulate the occurrence and development of human tumors. Jointly genes with similar expression patterns are likely to have related functions (64). For example, enrichment indicates that $B G N$-coexpressed genes are at least partially biologically connected in developing multiple cancers (65). The basic interaction between the neighboring genes is the "functional association'. The two proteins that both contribute jointly to a specific biological function can interact specifically without touching at all, such as when a transcription factor helps to regulate the expression and production of another protein, or when two enzymes exchange a specific substrate via diffusion. The exact molecular mechanisms in cancer associated with BGN remain unclear (66). BGN upregulation has been implicated in the inflammatory response triggered by transforming growth factor $\beta$ (TGF- $\beta$ ) $(8,67,68)$. In the PPI network, TGF- $\beta 3$ may play an important role to regulate the expression of BGN, however, the influence of TGF- $\beta 3$ needs to be further investigated.

\section{Discussion}

In the present study, the mRNA expression levels of BGN were systematically analyzed, and the results indicated that BGN was upregulated in various types of cancerous tissues, when compared with that in normal tissues. Previous studies have demonstrated that significantly increased levels of BGN are frequently detected in the clinical samples of patients with gastric (13), breast (69), colorectal (70), lung (71), ovarian (10) and pancreatic cancer (16). In addition, high expression of BGN in patients with solid cancer is significantly associated with poor outcome (15). Solid cancer include BLC, brain and CNS cancer, BC, cervical cancer, CC, EC, GC, HNC, kidney cancer, liver cancer, LC, melanoma, OC, pancreatic cancer, prostate cancer (72). Consistent with these studies, the present analyses demonstrated that BGN expression levels were increased in the majority of cancers, such as bladder, brain and central nervous system, breast, colorectal, esophageal, gastric, head and neck, lung, ovarian, and 28 subtype cancers, when compared with that in normal tissues. In addition, the current prognosis analyses revealed that high tissue BGN expression predicts worse survival in GC and OC. High BGN mRNA expression was associated with poor overall survival in patients with BLC, LSCC, and OSC. Therefore, BGN may be employed as either a novel prognostic biomarker or as a promising therapeutic target for human carcinomas, which is consistent with the findings of previous reports $(15,73)$. The 43 genes with similar expression patterns are likely to have related functions in the aggressive growth and metastasis of cancers (64). In the PPI network, the genes of AEBP1, MMP14, OLFML2B, PDGFRB, SERPINE1, SPARC, SFRP2, COL1A2, COL6A3, THBS2, COL5A2, COL11A1, FAP, MXRA5 and THY1 were upregulated in solid cancer tissues, and significantly associated with the overall survival of patients with cancer (74-82). Some genes in the PPI network, including AEBP1,OLFML2B, PDGFRB, SERPINE1, COL1A2, COL6A3, and THBS2 have been reported to be associated with metastasis, invasion and migration in cancer cells $(74,76,80,83,84)$. The enrichment of $\mathrm{BGN}$-coexpressed genes indicates that the proteins are at least partially biologically connected as a group (64). However, a detailed understanding of the mechanism associated with the function of BGN is currently lacking; therefore, further functional studies are warranted in the future. In addition, the BGN protein expression levels or the signaling pathways potentially involved require further investigation. Finally, studies utilizing larger cohorts, specific cancers, or larger prospective studies also need to be conducted in order to validate the prognostic values of BGN.

In summary, the present study comprehensively analyzed the mRNA expression levels and prognostic value of BGN in the most common types of cancer, and the results indicated that BGN exhibited significantly high expression levels in cancer tissues compared with normal tissues in multiple types of cancer. The present findings indicated that BGN may serve as a promising prognostic biomarker and therapeutic target for patients with BLCA and STAD.

\section{Acknowledgements}

Not applicable.

\section{Funding}

No funding was received.

\section{Availability of data and materials}

The datasets used and/or analyzed during the current study are available from the corresponding author on reasonable request.

\section{Authors' contributions}

SFZ conceived and designed the study. XJY, WJZ, LCL and ZPW made substantial contributions to the design of the current study, acquisition of data, interpretation of data and revising the manuscript. All authors read and approved the final manuscript.

\section{Ethics approval and consent to participate}

Not applicable.

\section{Patient consent for publication}

Not applicable.

\section{Competing interests}

The authors declare that they have no competing interests.

\section{References}

1. Chaker L, Falla A, van der Lee SJ, Muka T, Imo D, Jaspers L, Colpani V, Mendis S, Chowdhury R, Bramer WM, et al: The global impact of non-communicable diseases on macro-economic productivity: A systematic review. Eur J Epidemiol 30: 357-395, 2015.

2. Patel SA and DeMichele A: Adding adjuvant systemic treatment after neoadjuvant therapy in breast cancer: Review of the data. Curr Oncol Rep 19: 56, 2017. 
3. Miller KD, Nogueira L, Mariotto AB, Rowland JH, Yabroff KR, Alfano CM, Jemal A, Kramer JL and Siegel RL: Cancer treatment and survivorship statistics, 2019. CA Cancer J Clin 69: 363-385, 2019.

4. Siegel RL, Miller KD and Jemal A: Cancer statistics, 2019. CA Cancer J Clin 69: 7-34, 2019.

5. Ferlay J, Shin HR, Bray F, Forman D, Mathers C and Parkin DM: Estimates of worldwide burden of cancer in 2008: Int J Cancer 127: 2893-2917, 2010.

6. Geerkens C, Vetter U, Just W, Fedarko NS, Fisher LW, Young MF, Termine JD, Robey PG, Wöhrle D and Vogel W: The $\mathrm{X}$-chromosomal human biglycan gene $\mathrm{BGN}$ is subject to $\mathrm{X}$ inactivation but is transcribed like an X-Y homologous gene. Hum Genet 96: 44-52, 1995.

7. McBride OW, Fisher LW and Young MF: Localization of PGI (biglycan, BGN) and PGII (decorin, DCN, PG-40) genes on human chromosomes Xq13-qter and $12 \mathrm{q}$, respectively. Genomics 6: 219-225, 1990.

8. Nastase MV, Young MF and Schaefer L: Biglycan: A multivalent proteoglycan providing structure and signals. J Histochem Cytochem 60: 963-975, 2012.

9. Fallon JR and McNally EM: Non-Glycanated biglycan and LTBP4: Leveraging the extracellular matrix for Duchenne muscular dystrophy therapeutics. Matrix Biol 68-69: 616-627, 2018.

10. Kocbek V, Hevir-Kene N, Bersinger NA, Mueller MD and Rižner TL: Increased levels of biglycan in endometriomas and peritoneal fluid samples from ovarian endometriosis patients. Gynecol Endocrinol 30: 520-524, 2014.

11. Jacobsen F, Kraft J, Schroeder C, Hube-Magg C, Kluth M, Lang DS, Simon R, Sauter G, Izbicki JR, Clauditz TS, et al: Up-regulation of biglycan is associated with poor prognosis and PTEN deletion in patients with prostate cancer. Neoplasia 19: 707-715, 2017.

12. Weber CK, Sommer G, Michl P, Fensterer H, Weimer M, Gansauge F, Leder G, Adler G and Gress TM: Biglycan is overexpressed in pancreatic cancer and induces G1-arrest in pancreatic cancer cell lines. Gastroenterology 121: 657-667, 2001.

13. Hu L, Duan YT, Li JF, Su LP, Yan M, Zhu ZG, Liu BY and Yang QM: Biglycan enhances gastric cancer invasion by activating FAK signaling pathway. Oncotarget 5: 1885-1896, 2014.

14. Xing X, Gu X, Ma T and Ye H: Biglycan up-regulated vascular endothelial growth factor (VEGF) expression and promoted angiogenesis in colon cancer. Tumour Biol 36: 1773-1780, 2015.

15. Wang B, Li GX, Zhang SG, Wang Q, Wen YG, Tang HM, Zhou CZ, Xing AY, Fan JW, Yan DW, et al: Biglycan expression correlates with aggressiveness and poor prognosis of gastric cancer. Exp Biol Med (Maywood) 236: 1247-1253, 2011.

16. Aprile G, Avellini C, Reni M, Mazzer M, Foltran L, Rossi D, Cereda S, Iaiza E, Fasola G and Piga A: Biglycan expression and clinical outcome in patients with pancreatic adenocarcinoma. Tumor Biol 34: 131-137, 2013.

17. Rhodes DR, Yu J, Shanker K, Deshpande N, Varambally R, Ghosh D, Barrette T, Pandey A and Chinnaiyan AM: ONCOMINE: A cancer microarray database and integrated data-mining platform. Neoplasia 6: 1-6, 2004.

18. Anaya J: OncoLnc: Linking TCGA survival data to mRNAs, miRNAs, and lncRNAs. PeerJ Computer Sci 2: e67, 2016.

19. Chandrashekar DS, Bashel B, Balasubramanya $\mathrm{SAH}$, Creighton CJ, Ponce-Rodriguez I, Chakravarthi BVSK and Varambally S: UALCAN: A portal for facilitating tumor subgroup gene expression and survival analyses. Neoplasia 19: 649-658, 2017

20. Györffy B, Lanczky A, Eklund AC, Denkert C, Budczies J, Li Q and Szallasi Z: An online survival analysis tool to rapidly assess the effect of 22,277 genes on breast cancer prognosis using microarray data of 1,809 patients. Breast Cancer Res Treat 123: 725-731, 2010.

21. Győrffy B, Lánczky A and Szállási Z: Implementing an online tool for genome-wide validation of survival-associated biomarkers in ovarian-cancer using microarray data from 1287 patients. Endocr Relat Cancer 19: 197-208, 2012.

22. Győrffy B, Surowiak P, Budczies J and Lánczky A: Online survival analysis software to assess the prognostic value of biomarkers using transcriptomic data in non-small-cell lung cancer. PLoS One 8: e82241, 2013.
23. Szász AM, Lánczky A, Nagy Á, Förster S, Hark K, Green JE, Boussioutas A, Busuttil R, Szabó A and Győrffy B: Cross-validation of survival associated biomarkers in gastric cancer using transcriptomic data of 1,065 patients. Oncotarget 7: 49322-49333, 2016.

24. Szklarczyk D, Franceschini A, Wyder S, Forslund K, Heller D, Huerta-Cepas J, Simonovic M, Roth A, Santos A, Tsafou KP, et al: STRING v10: Protein-protein interaction networks, integrated over the tree of life. Nucleic Acids Res 43: D447-D452, 2015.

25. Chen X, Cheung ST, So S, Fan ST, Barry C, Higgins J, Lai KM, Ji J, Dudoit S, Ng IO, et al: Gene expression patterns in human liver cancers. Mol Biol Cell 13: 1929-1939, 2002.

26. Higgins JP, Shinghal R, Gill H, Reese JH, Terris M, Cohen RJ, Fero M, Pollack JR, van de Rijn M and Brooks JD: Gene expression patterns in renal cell carcinoma assessed by complementary DNA microarray. Am J Pathol 162: 925-932, 2003.

27. Iacobuzio-Donahue CA, Maitra A, Olsen M, Lowe AW, van Heek NT, Rosty C, Walter K, Sato N, Parker A, Ashfaq R, et al: Exploration of global gene expression patterns in pancreatic adenocarcinoma using cDNA microarrays. Am J Pathol 162: 1151-1162, 2003.

28. Buchholz M, Braun M, Heidenblut A, Kestler HA, Klöppel G, Schmiegel W, Hahn SA, Lüttges J and Gress TM: Transcriptome analysis of microdissected pancreatic intraepithelial neoplastic lesions. Oncogene 24: 6626-6636, 2005.

29. Segara D, Biankin AV, Kench JG, Langusch CC, Dawson AC, Skalicky DA, Gotley DC, Coleman MJ, Sutherland RL and Henshall SM: Expression of HOXB2, a retinoic acid signaling target in pancreatic cancer and pancreatic intraepithelial neoplasia. Clin Cancer Res 11: 3587-3596, 2005.

30. Badea L, Herlea V, Dima SO, Dumitrascu T and Popescu I: Combined gene expression analysis of whole-tissue and microdissected pancreatic ductal adenocarcinoma identifies genes specifically overexpressed in tumor epithelia. Hepatogastroenterology 55: 2016-2027, 2008.

31. Mas VR, Maluf DG, Archer KJ, Yanek K, Kong X, Kulik L, Freise CE, Olthoff KM, Ghobrial RM, McIver P and Fisher R: Genes involved in viral carcinogenesis and tumor initiation in hepatitis C virus-induced hepatocellular carcinoma. Mol Med 15: 85-94, 2009.

32. Yusenko MV, Kuiper RP, Boethe T, Ljungberg B, van Kessel AG and Kovacs G: High-resolution DNA copy number and gene expression analyses distinguish chromophobe renal cell carcinomas and renal oncocytomas. BMC Cancer 9: 152, 2009.

33. Roessler S, Jia HL, Budhu A, Forgues M, Ye QH, Lee JS, Thorgeirsson SS, Sun Z, Tang ZY, Qin LX and Wang XW: A unique metastasis gene signature enables prediction of tumor relapse in early-stage hepatocellular carcinoma patients. Cancer Res 70: 10202-10212, 2010.

34. Franzmann E: Carcinoma. In: Encyclopedia of Behavioral Medicine. Gellman MD and Turner JR (eds.) Springer New York, New York, NY, pp329-330, 2013.

35. Blaveri E, Simko JP, Korkola JE, Brewer JL, Baehner F, Mehta K, Devries S, Koppie T, Pejavar S, Carroll P and Waldman FM: Bladder cancer outcome and subtype classification by gene expression. Clin Cancer Res 11: 4044-4055, 2005.

36. Bredel M, Bredel C, Juric D, Harsh GR, Vogel H, Recht LD and Sikic BI: Functional network analysis reveals extended gliomagenesis pathway maps and three novel MYC-interacting genes in human gliomas. Cancer Res 65: 8679-8689, 2005.

37. Ma XJ, Dahiya S, Richardson E, Erlander M and Sgroi DC: Gene expression profiling of the tumor microenvironment during breast cancer progression. Breast Cancer Res 11: R7, 2009.

38. Curtis C, Shah SP, Chin SF, Turashvili G, Rueda OM, Dunning MJ, Speed D, Lynch AG, Samarajiwa S, Yuan Y, et al: The genomic and transcriptomic architecture of 2,000 breast tumours reveals novel subgroups. Nature 486: 346-352, 2012.

39. Karnoub AE, Dash AB, Vo AP, Sullivan A, Brooks MW, Bell GW, Richardson AL, Polyak K, Tubo R and Weinberg RA: Mesenchymal stem cells within tumour stroma promote breast cancer metastasis. Nature 449: 557-563, 2007.

40. Perou CM, Sørlie T, Eisen MB, van de Rijn M, Jeffrey SS, Rees CA, Pollack JR, Ross DT, Johnsen H, Akslen LA, et al: Molecular portraits of human breast tumours. Nature 406: 747-752, 2000.

41. Zhao H, Langerod A, Ji Y, Nowels KW, Nesland JM, Tibshirani R, Bukholm IK, Kåresen R, Botstein D, Børresen-Dale AL and Jeffrey SS: Different gene expression patterns in invasive lobular and ductal carcinomas of the breast. Mol Biol Cell 15: 2523-2536, 2004. 
42. Cancer Genome Atlas Network: Comprehensive molecular portraits of human breast tumours. Nature 490: 61-70, 2012

43. Ciriello G, Gatza ML, Beck AH, Wilkerson MD, Rhie SK, Pastore A, Zhang H, McLellan M, Yau C, Kandoth C, et al Comprehensive molecular portraits of invasive lobular breast cancer. Cell 163: 506-519, 2015.

44. Kaiser S, Park YK, Franklin JL, Halberg RB, Yu M, Jessen WJ, Freudenberg J, Chen X, Haigis K, Jegga AG, et al: Transcriptional recapitulation and subversion of embryonic colon development by mouse colon tumor models and human colon cancer. Genome Biol 8: R131, 2007.

45. Skrzypczak M, Goryca K, Rubel T, Paziewska A, Mikula M, Jarosz D, Pachlewski J, Oledzki J and Ostrowski J: Modeling oncogenic signaling in colon tumors by multidirectional analyses of microarray data directed for maximization of analytical reliability. PLoS One 5: pii: e13091, 2010.

46. Graudens E, Boulanger V, Mollard C, Mariage-Samson R, Barlet X, Grémy G, Couillault C, Lajémi M, Piatier-Tonneau D, Zaborski P, et al: Deciphering cellular states of innate tumor drug responses. Genome Biol 7: R19, 2006.

47. Cancer Genome Atlas Network; Muzny DM, Bainbridge MN, Chang K, Dinh HH, Drummond JA, Fowler G, Kovar CL, Lewis LR, Morgan MB, et al: Comprehensive molecular characterization of human colon and rectal cancer. Nature 487: 330-337, 2012.

48. Gaedcke J, Grade M, Jung K, Camps J, Jo P, Emons G, Gehoff A, Sax U, Schirmer M, Becker $\mathrm{H}$, et al: Mutated KRAS results in overexpression of DUSP4, a MAP-kinase phosphatase, and SMYD3, a histone methyltransferase, in rectal carcinomas. Genes Chromosomes Cancer 49: 1024-1034, 2010.

49. Hong Y, Downey T, Eu KW, Koh PK and Cheah PY: A 'metastasis-prone' signature for early-stage mismatch-repair proficient sporadic colorectal cancer patients and its implications for possible therapeutics. Clin Exp Metastasis 27: 83-90, 2010

50. Su H, Hu N, Yang HH, Wang C, Takikita M, Wang QH, Giffen C, Clifford R, Hewitt SM, Shou JZ, et al: Global gene expression profiling and validation in esophageal squamous cell carcinoma and its association with clinical phenotypes. Clin Cancer Res 17: 2955-2966, 2011

51. Hu N, Clifford RJ, Yang HH, Wang C, Goldstein AM, Ding T, Taylor PR and Lee MP: Genome wide analysis of DNA copy number neutral loss of heterozygosity (CNNLOH) and its relation to gene expression in esophageal squamous cell carcinoma. BMC Genomics 11: 576, 2010.

52. Hao Y, Triadafilopoulos G, Sahbaie P, Young HS, Omary MB and Lowe AW: Gene expression profiling reveals stromal genes expressed in common between Barrett's esophagus and adenocarcinoma. Gastroenterology 131: 925-933, 2006.

53. Chen X, Leung SY, Yuen ST, Chu KM, Ji J, Li R, Chan AS, Law S, Troyanskaya OG, Wong J, et al: Variation in gene expression patterns in human gastric cancers. Mol Biol Cell 14: 3208-3215, 2003

54. Cho JY, Lim JY, Cheong JH, Park YY, Yoon SL, Kim SM, Kim SB, Kim H, Hong SW, Park YN, et al: Gene expression signature-based prognostic risk score in gastric cancer. Clin Cancer Res 17: 1850-1857, 2011

55. Wang Q, Wen YG, Li DP, Xia J, Zhou CZ, Yan DW, Tang HM and Peng ZH: Upregulated INHBA expression is associated with poor survival in gastric cancer. Med Oncol 29: 77-83, 2012.

56. D'Errico M, de Rinaldis E, Blasi MF, Viti V, Falchetti M, Calcagnile A, Sera F, Saieva C, Ottini L, Palli D, et al: Genome-wide expression profile of sporadic gastric cancers with microsatellite instability. Eur J Cancer 45: 461-469, 2009.

57. Cui J, Chen Y, Chou WC, Sun L, Chen L, Suo J, Ni Z, Zhang M, Kong X, Hoffman LL, et al: An integrated transcriptomic and computational analysis for biomarker identification in gastric cancer. Nucleic Acids Res 39: 1197-1207, 2011.

58. Frierson HF Jr, El-Naggar AK, Welsh JB, Sapinoso LM, Su AI, Cheng J, Saku T, Moskaluk CA and Hampton GM: Large scale molecular analysis identifies genes with altered expression in salivary adenoid cystic carcinoma. Am J Pathol 161: 1315-1323, 2002.

59. Talbot SG, Estilo C, Maghami E, Sarkaria IS, Pham DK, O-Charoenrat P, Socci ND, Ngai I, Carlson D, Ghossein R, et al: Gene expression profiling allows distinction between primary and metastatic squamous cell carcinomas in the lung. Cancer Res 65: 3063-3071, 2005.
60. Welsh JB, Zarrinkar PP, Sapinoso LM, Kern SG, Behling CA Monk BJ, Lockhart DJ, Burger RA and Hampton GM: Analysis of gene expression profiles in normal and neoplastic ovarian tissue samples identifies candidate molecular markers of epithelial ovarian cancer. Proc Natl Acad Sci USA 98: 1176-1181, 2001

61. Bonome T, Levine DA, Shih J, Randonovich M, Pise-Masison CA, Bogomolniy F, Ozbun L, Brady J, Barrett JC, Boyd J and Birrer MJ: A gene signature predicting for survival in suboptimally debulked patients with ovarian cancer. Cancer Res 68: 5478-5486, 2008

62. Cancer Genome Atlas Research Network: Integrated genomic analyses of ovarian carcinoma. Nature 474: 609-615, 2011.

63. Riker AI, Enkemann SA, Fodstad O, Liu S, Ren S, Morris C, Xi Y, Howell P, Metge B, Samant RS, et al: The gene expression profiles of primary and metastatic melanoma yields a transition point of tumor progression and metastasis. BMC Med Genomics 1: 13, 2008

64. Tang Z, Li C, Kang B, Gao G, Li C and Zhang Z: GEPIA: A web server for cancer and normal gene expression profiling and interactive analyses. Nucleic Acids Res 45: W98-W102, 2017.

65. Szklarczyk D, Gable AL, Lyon D, Junge A, Wyder S, Huerta-Cepas J, Simonovic M, Doncheva NT, Morris JH, Bork P, et al: STRING v11: Protein-protein association networks with increased coverage, supporting functional discovery in genome-wide experimental datasets. Nucleic Acids Res 47: D607-D613, 2019.

66. Appunni S, Anand V, Khandelwal M, Gupta N, Rubens M and Sharma A: Small leucine rich proteoglycans (decorin, biglycan and lumican) in cancer. Clin Chim Acta 491: 1-7, 2019.

67. Schaefer L, Babelova A, Kiss E, Hausser HJ, Baliova M, Krzyzankova M, Marsche G, Young MF, Mihalik D, Götte M, et al: The matrix component biglycan is proinflammatory and signals through Toll-like receptors 4 and 2 in macrophages. J Clin Invest 115: 2223-2233, 2005.

68. Hildebrand $\mathrm{A}$, Romaris $\mathrm{M}$, Rasmussen LM, Heinegård D, Twardzik DR, Border WA and Ruoslahti E: Interaction of the small interstitial proteoglycans biglycan, decorin and fibromodulin with transforming growth factor beta. Biochem J 302: 527-534, 1994.

69. Bischof AG, Yüksel D, Mammoto T, Mammoto A, Krause S and Ingber DE: Breast cancer normalization induced by embryonic mesenchyme is mediated by extracellular matrix biglycan. Integr Biol (Camb) 5: 1045-1056, 2013.

70. Liu B, Xu T, Xu X, Cui Y and Xing X: Biglycan promotes the chemotherapy resistance of colon cancer by activating NF-kappaB signal transduction. Mol Cell Biochem 449: 285-294, 2018.

71. Yang Z, Wen Y, Qian L and Hospital Z: Up-regulation of biglycan is associated with malignant phenotype of nonsmall cell lung cancer. J Med Res 45, 41-46, 2016.

72. Ferlay J, Colombet M, Soerjomataram I, Mathers C, Parkin DM, Piñeros M, Znaor A and Bray F: Estimating the global cancer incidence and mortality in 2018: GLOBOCAN sources and methods. Int J Cancer 144: 1941-1953, 2019.

73. Appunni S, Anand V, Khandelwal M, Seth A, Mathur S and Sharma A: Altered expression of small leucine-rich proteoglycans (Decorin, Biglycan and Lumican): Plausible diagnostic marker in urothelial carcinoma of bladder. Tumour Biol 39: 1010428317699112, 2017.

74. Liu JY, Jiang L, Liu JJ, He T, Cui YH, Qian F and Yu PW: AEBP1 promotes epithelial-mesenchymal transition of gastric cancer cells by activating the NF- $\kappa \mathrm{B}$ pathway and predicts poor outcome of the patients. Sci Rep 8: 11955, 2018.

75. Kasurinen A, Gramolelli S, Hagström J, Laitinen A, Kokkola A, Miki Y, Lehti K, Yashiro M, Ojala PM, Böckelman C and Haglund C: High tissue MMP14 expression predicts worse survival in gastric cancer, particularly with a low PROX1. Cancer Med 8: 6995-7005, 2019.

76. Liu J, Liu Z, Zhang X, Gong T and Yao D: Bioinformatic exploration of OLFML2B overexpression in gastric cancer base on multiple analyzing tools. BMC Cancer 19: 227, 2019.

77. Wang G, Shi B, Fu Y, Zhao S, Qu K, Guo Q, Li K and She J: Hypomethylated gene NRP1 is co-expressed with PDGFRB and associated with poor overall survival in gastric cancer patients. Biomed Pharmacother 111: 1334-1341, 2019.

78. Liao P, Li W, Liu R, Teer JK, Xu B, Zhang W, Li X, Mcleod HL and $\mathrm{He}$ Y: Genome-scale analysis identifies SERPINE1 and SPARC as diagnostic and prognostic biomarkers in gastric cancer. Onco Targets Ther 11: 6969-6980, 2018. 
79. Wang H, Duan XL, Qi XL, Meng L, Xu YS, Wu T and Dai PG: Concurrent Hypermethylation of SFRP2 and DKK2 Activates the $\mathrm{Wnt} / \beta$-catenin pathway and is associated with poor prognosis in patients with gastric cancer. Mol Cells 40: 45-53, 2017.

80. Ao R, Guan L, Wang Y and Wang JN: Silencing of COL1A2, COL6A3, and THBS2 inhibits gastric cancer cell proliferation, migration, and invasion while promoting apoptosis through the PI3k-Akt signaling pathway. J Cell Biochem 119: 4420-4434, 2018.

81. Zhuo C, Li X, Zhuang H, Tian S, Cui H, Jiang R, Liu C, Tao R and Lin X: Elevated THBS2, COL1A2, and SPP1 expression levels as predictors of gastric cancer prognosis. Cell Physiol Biochem 40: $1316-1324,2016$.

82. Hao S, Lv J, Yang Q, Wang A, Li Z, Guo Y and Zhang G: Identification of key genes and circular RNAs in human gastric cancer. Med Sci Monit 25: 2488-2504, 2019.
83. Suzuki S, Dobashi Y, Hatakeyama Y, Tajiri R, Fujimura T, Heldin $\mathrm{CH}$ and Ooi A: Clinicopathological significance of platelet-derived growth factor (PDGF)-B and vascular endothelial growth factor-A expression, PDGF receptor- $\beta$ phosphorylation, and microvessel density in gastric cancer. BMC Cancer 10: 659, 2010.

84. Mazzoccoli G, Pazienza V, Panza A, Valvano MR, Benegiamo G, Vinciguerra M, Andriulli A and Piepoli A: ARNTL2 and SERPINE1: Potential biomarkers for tumor aggressiveness in colorectal cancer. J Cancer Res Clin Oncol 138: 501-511, 2012.

(i) $\Theta$ This work is licensed under a Creative Commons Attribution-NonCommercial-NoDerivatives 4.0 International (CC BY-NC-ND 4.0) License. 